\title{
Food waste: a political ecology approach
}

\author{
Jordi Gascón ${ }^{1}$ \\ Universitat de Lleida, Catalonia, Spain
}

\begin{abstract}
Food waste is the loss of perfectly edible food products. It is a wide-ranging phenomenon: a substantial part of agricultural production is never consumed. The prevalent, most widespread paradigm regarding this phenomenon holds that it is due to inadequate logistics and technology, or to poor management of food on the part of end users. However, an analysis from a political ecology standpoint allows a different interpretation: the root of the problem lies in the hegemonic agrofood system and the unequal power relationships between the actors in the agrofood chain.
\end{abstract}

Key words: Food waste, agriculture, agrofood system, supermarkets, political ecology

\section{Résumé}

Le gaspillage alimentaire est la perte de la nourriture produite et parfaitement comestible. C'est un phénomène de grande dimension: une partie substantielle de la production agricole mondiale n'est pas consommée. Le paradigme dominant et le plus répandu sur ce phénomène considère qu'il est dû à des insuffisances logistiques et technologiques, ou à la mauvaise gestion de la nourriture par le consommateur final. Cependant, une analyse de l'écologie politique permet une lecture différente: la racine du problème est dans le modèle agroalimentaire hégémonique, et dans les relations de pouvoir inégales qui existent entre les acteurs qui composent la chaîne agroalimentaire.

Mots clés: Gaspillage alimentaire, agriculture, système agroalimentaire, supermarchés, écologie politique

\section{Resumen}

El desperdicio alimentario es la pérdida de los alimentos producidos y perfectamente comestibles. Se trata de un fenómeno de grandes dimensiones: una parte sustancial de la producción agraria mundial no llega a ser consumida. El paradigma dominante y más difundido sobre este fenómeno considera que se debe a insuficiencias logísticas y tecnológicas, o a la mala gestión de los alimentos por parte del consumidor final. Sin embargo, un análisis desde la Ecología Política permite una lectura diferente: la raíz del problema está en el modelo agroalimentario hegemónico, y en las desiguales relaciones de poder que existen entre los actores que conforman la cadena agroalimentaria.

Palabras clave: Desperdicio alimentario, agricultura, sistema agro-alimentario, supermercados, ecología política

\footnotetext{
1 Dr. Jordi Gascón, Visiting Professor, Departament d'Història Social, Universitat de Lleida, and Observatori de l'Alimentació ODELA, Universitat de Barcelona, Catalonia, Spain. Email: jordigascon "at" hahs.udl.cat. This research was supported by Ministry of Higher Education, Science, Technology and Innovation (Secretaría de Educación Superior, Ciencia, Tecnología e Innovación - SENESCYT) of the Republic of Ecuador (Prometheus Project). I thank Professor Francois Houtart $(\dagger)$, Xavier Montagut (Xarxa de Consum Solidari, Catalonia) and members of the Food Observatory University of Barcelona (Observatori de l'Alimentació - Universitat de Barcelona) for their comments that greatly improved the manuscript.
} 


\section{Introduction}

The hegemonic agrofood model is characterized by its organizational complexity and the enormous distances traveled by foods and the agricultural supplies used to produce them. The inputs enabling the production of a product found on the supermarket shelf can come from places that are tens of thousands of miles apart. From a food perspective, the planet has been fragmented and organized depending on the role that each territory plays in this model. And certain actors have emerged as dominant players, namely, agrofood, transport, and agrochemical corporations, among which retail and supermarket chains play a prominent role (Freidberg 2007; Lappe, Collins and Rosset 1998). However, some authors have stressed that despite their dominant role, these corporations do not have absolute control over the system. In fact, as a result of the breadth and complexity of the agrofood chain, large corporations are often unfamiliar with the functioning and production processes behind many of the products they sell and the agricultural ingredients with which they are made. There are murky areas that fall beyond their control. And this ignorance has become a risk (Freidberg 2017; Mol and Bulkeley 2002).

How to manage these food risks is the subject of political and social debate. This includes not only health risks, but also environmental and social ones. The social movements demanding the adoption of ethical and ecological principles in the agrofood industry grow larger each day (Freidberg 2004; Holt-Giménez 2011). These movements advocate paradigms related to political ecology, such as food sovereignty and food justice. Such paradigms do not focus on advocating for consumer rights, creating a market niche for more sustainable consumption, or supervising a given stage of the agrofood chain. Rather, they take a more holistic view, whereby the root of food risks and problems lies in the hegemonic agribusiness model. Specifically, these risks and problems are due to the fact that this model turns agriculture into an industry that produces commodities instead of food and establishes deeply unequal production relations (Cadieux and Slocum 2015; Siniscalchi 2013).

One of the ecological and social risks of the agribusiness model is the production of food waste (Gille 2012). Curiously, although the movements advocating for food sovereignty and food justice have studied the causes and effects of food overproduction, they have not focused on food waste, a phenomenon that is largescale and directly related to production (Montagut and Gascón 2014). The FAO calculates that one third of the food produced on the planet is never consumed. Food waste throughout the agrofood chain seems to fall into one of the aforementioned "murky areas" beyond the system's control. How and why is food waste generated? Who is responsible for it?

The hegemonic and most widespread food waste paradigm suggests that it is due to logistical and technical shortcomings in the production, transport, and processing stages, or to poor food management by end consumers. In other words: the "murky areas" are the result of system dysfunctions that can be tackled by applying technological solutions and awareness-raising campaigns. This article aims to assess this view. To this end, it will take a political ecology and food sovereignty approach that considers the characteristics of the hegemonic agrofood model with a view to offering a counter-hypothesis: what if the root of the phenomenon lies in that model itself, and in the unequal power relations that characterize it?

First, we will examine the perspectives on which the two hypotheses are based. We will see that adopting one or the other can increase or reduce the scope of the problem or even lead to the identification of different parties as being responsible. Next, we will look into the interests lying behind each definition. To do so, we will analyze when and how food waste takes place. We will focus on the first link in the agrofood chain: production.

\section{Two definitions}

Food waste (...) may thus be defined as a less than maximum use of nutrients for human consumption (...) Food waste is the destruction or deterioration of food or the use of crops, livestock and livestock products in ways which return relatively little human food value. (Kling 1943: 850) 
Per definition, food losses or waste are the masses of food lost or wasted in the part of food chains leading to edible products going to human consumption. (Gustavsson, Cederberg and Sonesson 2011: 2)

The approaches under which the phenomenon of food waste has been analyzed are very diverse. But all of them agree on two points. One is that it is a wide-ranging phenomenon. A study commissioned by the EU determined that on average $179 \mathrm{~kg}$ of food per person per year were wasted in the European Union (BIO Intelligence Service 2012). And it must be recalled that as of 2017 the population of the EU, including the UK, exceeded 510 million. The other point of agreement is that the data provided in some studies are approximations; there is no way of determining the actual volumes we are talking about. For instance, the Soil Association (n.d.) raises the volume of food waste per person per year in the European Union to between 280 and $380 \mathrm{~kg}$; in other words, it virtually doubles the BIO Intelligence estimate.

One reason for this difference in calculations is that the measurement mechanisms used are very diverse, which complicates the process of making comparisons and gathering data (Parfitt, Barthel and Macnaughton 2010; Stuart 2009). But a further reason is that no agreement exists as to what should be considered "food waste." This is highlighted by the two quotes at the beginning of this section.

There is a space of almost seven decades between the two definitions. The first, by William Kling (1943), published in the American Journal of Agricultural Economics, was the first to be put forward about this phenomenon. It was composed at a very particular historical moment. The US had just entered World War II, and the reduction in capital and labor devoted to farming in order to support the war effort was compounded by the need to feed hundreds of thousands of soldiers scattered around the world, as well as the armies and citizens of other allied territories whose agriculture had been devastated. Once the war was over, in a context of swift and sustained growth of agricultural output, the issue of food waste lapsed into a long period of academic and political lethargy, and Kling's definition was forgotten.

The second, more recent definition was advanced for the first time in Global food losses and food waste, the programmatic document of the Food and Agriculture Organization of the United Nations (FAO) on food waste. This makes it the canonical definition of the phenomenon: it is the one used, with certain exceptions, by public institutions, consultants and academics. It is a definition that arises in a global context characterized by a paradox. On the one hand the highest levels of structural food poverty have been attained. But at the same time we are experiencing, or suffering from, overproduction of certain agrofood products, generating tensions in the markets and exerting pressure on public policies.

It is pure formalism to feign equanimity when composing the definitions of social phenomena. However, save when they are written by authors who fall within the definition of heterodoxy, they are the product of their age and the result of hegemonic thinking. These two definitions are no exception. Behind them lie diametrically opposed conceptions of food waste. As we will discuss later, the 1943 definition includes much more than the one dating from 2011. Let us use a technical term that explains this disparity: the unit of calculation used by either of them to calculate food waste. The FAO definition talks about units of mass. Kling's definition refers to energy (nutrients).

Hence, the FAO only considers as food waste the volume of edible products that are not ingested. And then it further reduces that quantity, without explaining why, to products intended for human consumption only. It thus leaves out of the definition - and the phenomenon - the loss of produce used as food for cattle or farm animals used to feed humans.

Kling goes beyond this: if the calculation is made in terms of nutrients, one should take into account not only the loss of food, but also the loss of the resources used to produce it. That is, it must also include the food that cannot be produced due to the loss of agricultural resources. Calculating waste in terms of volume makes it difficult to consider the waste of resources (land, water, agricultural inputs, etc.) that may be taking place during the production process, or the energy expended during transportation. These are factors that cannot be measured in units of mass (Gascón 2018), which makes them what political ecologists refer to as an "externality": a social cost not taken into account by conventional accounting and ascribed to certain communities, social groups or to future generations (Martínez Alier 1994). Speaking in terms of nutrients 
brings us close to a computation model that can include all these elements, in a similar manner to how political ecology claims to make calculations based on energy inputs and outputs instead of using monetary valuations (Carpintero 2006; Willow 2014). Or, at any rate, it makes us think that all these elements should be considered when analyzing the phenomenon.

What has happened over these past seven decades so that we have gone from a broad definition to a much narrower one? Might it have to do with the progressive level of control that the transnational agrofood industry has accumulated over the intervening period? Let us not forget that such control not only affects our consumption habits and agricultural policies; it also impacts the outlook and trends in agrofood research (Stedile 2010; Swinnen 2010).

As the agrofood chain is long and complex, we will focus on just one of its stages: production. Several factors explain waste during the food production stage. They involve constraints that force farmers to adopt certain production strategies in order not to be marginalized from the market. For organizational purposes, we have classified them into two groups: those that cause a waste of produce, and those that give rise to a waste of production resources.

\section{Waste in the food production process (1): waste of produce}

In a process that has been going on since the middle of the last century, large retail chains, i.e., supermarkets, have become the link in the chain that controls the agrofood process. Today it is difficult for Western consumers to avoid entering one of their stores in order to purchase part or virtually all of the food products they need to meet their household needs. Supermarkets have progressively marginalized small neighborhood grocery stores through different strategies: low pricing policies, in some cases below cost price (unfair competition); promotional campaigns; an extremely diverse offering of product brands made possible by the large size of their outlets; psychological strategies to shape consumer habits; and access to market research; etc. (Fjelda and Sommera 1982; Pisani and Yoskowitz 2012; Ronald, William and Harper 1967; Wood 2007). One contributing factor is the lesser time available for reproductive work in households; supermarkets seem to save precious time by concentrating in the same location all the household products consumed on a daily basis (Macías Huerta and Valdivia Preciado 2003; Moisio, Arnould and Price 2004). This reduction in the time available for reproductive work is also behind the disappearance of traditional food preparation and preservation habits. The result is an expansion in pre-cooked or semi-prepared food. In Spain, four out of five food purchases are carried out in supermarkets. Moreover, the number of retail chains is small: only five companies control $55 \%$ of food sales, and one in four food products purchased come from a single retail chain (Montagut and Vivas 2007). This situation has given such pre-eminence to supermarkets that they have ended up controlling, as stated earlier, the entire agrofood chain. A sort of bottleneck between producer and consumer has been established.

Their control of the agrofood chain gives supermarkets a high measure of control over the production process (Hattersley, Isaac and Burch 2013; Reardon and Hopkins 2006; Ribeiro 2007). Such control is exerted over both local producers and those that, though located thousands of kilometers away from the point of consumption, who have nevertheless become suppliers. Farmers now have to adapt their production practices and structures to the demands of this oligopolistic market. If they do not succeed in doing so, they will be marginalized from the market (Dolan and Humphrey 2000; Freidberg 2003; Ghezán, Mateos and Viteri 2002; Schwentesius and Gómez 2002). One such imposition that draws the most media attention and coverage involves prices: supermarket chains exert pressure on producers to lower prices in order to increase their profit margins (COAG 2014; Richards, Bjørkhaug, Lawrence and Hickman 2013).

However, there are other factors of such control directly affecting food waste. Here we shall discuss three of them: product appearance requirements, planning of production according to the logistical needs of large retail chains, and competition among producers to avoid being marginalized from the market.

\section{a) Requirements regarding product appearance}

One of the requirements with the highest impact on food waste regards the appearance that supplied products must have: size, texture, color and shape. Nor are any bruises or flaws accepted. However, traditional 
peasant farming generates products of widely differing appearance, with a prevalence of small-sized items. A further requirement is that the product should be easy to handle and consume (fruit that easy to peel, seedless, etc.). In addition, products are often required to conform to hygiene and health standards that give excessive weight to organic contamination while minimizing the importance of chemical contamination (Binimelis, Escurriol and Rivera-Ferré 2012). All these requirements call for standardizing production methods (Gorenstein 1998; Prieto et al. 2008; Rimal 2008). Hence, in order to secure access to the market, farmers are forced to implement a certain technology package to ensure such standardization, characterized by the use of certain inputs: hybrid seeds or, more recently, genetically modified organisms, as well as pesticides, weedkillers, fungicides and industrial fertilizers. Farmers have no choice but to direct their efforts to producing uniform harvests with good-looking products that allow easy industrial handling. Moreover, the cost of such technology leads them to specialize in one or a few products.

However, despite the use of such technology and the efforts of producers, a substantial part of agricultural production does not meet the quality requirements imposed by large retailers. There is scant data on the quantities of perfectly wholesome products suitable for human consumption that are lost in the fields due to failure to conform to the required standards. This information is essential in order to avoid such waste. Tristram Stuart (2009), leader of the Feeding the 5000 campaign, calculated that $25 \%$ to $40 \%$ of vegetable and market garden produce never reached the market due to such requirements (McGrath 2013). A study pending publication conducted by the authors of this article on fruit production in Lleida (Catalonia) reveals that $30 \%$ to $40 \%$ of stone fruit is rejected in the field due to failure to conform to the required standards (Gascón, Larrea, Ribas and Solà 2017). Along the same lines, Stuart pointed out that, in a study conducted by waste management company Biffa, it was calculated that in the UK between one third and half of fruit and vegetable produce was rejected in British fields. A study on British strawberries revealed that $10 \%$ to $30 \%$ of the strawberry harvest falls under the Class II, or non-marketable category, and is left to rot in the field (Warner, Tzilivakis and Lewis 2005).

These calculations are broad estimates and focus on specific products and territories. They do not allow for general extrapolation. Stuart (2009) complained of the scant interest in revealing such information. Devin and Richards (2018) pointed out that the supermarkets' corporate social responsibility policies call for concealing these figures and their own role in the process. Still, they reflect the magnitude of this phenomenon. Moreover, hygiene and health regulations make it hard for small and medium-sized producers to market rejected produce. For example, an organic farmer in Fraga, in Franja de Ponent (Aragón, Spain), a region renowned for its fruit produce, explained that he had been forbidden from making juice with the fruit he was unable to sell, as he did not have the facilities considered suitable and required by the applicable regulations. Building such facilities represented a cost that made low-volume juice production financially infeasible.

A major part of rejected produce is used in the production of organic fertilizers. For instance, British waste management company Biffa cut the amount of waste sent to landfills by frozen food companies employing its services by $21 \%$ thanks to the production of compost (Waste Management World 2013). It should be noted that scientific research aimed at enhancing the efficiency of this process has increased since the beginning of this century (e.g. Arancon et al. 2005; Awasthi et al. 2017; Kumar, Ou and Lin 2010; Lee et al. 2004). Indeed, the possibility is even being considered of using this resource to produce edible mushrooms (Rosales, Rodríguez Couto and Sanromán 2002). In such cases, the produce turned down by retailers is incorporated back into the production process. Other proposed projects call for generating energy from the resulting organic waste (Kiran et al. 2014; Yasin et al. 2013).

However, the outcome in terms of energy and nutrients does not appear to be positive. The cost of producing a wasted food item greatly exceeds the potential income resulting from its use as an agricultural input or as a source of energy. Although recycling reduces the nutrient loss caused by food waste (as well as management problems due to waste accumulation) it does not make up for it.

\section{b) Planning of production according to the interests and needs of large retailers}

'Lean manufacturing' is a corporate management strategy consisting in the removal or reduction of any deficiencies in the production/marketing chain that consume resources without creating value. Such 
deficiencies may involve product flaws, unnecessary goods transfers, excess processing, a piled up inventory, or overproduction. Large food retailers are looking into and implementing this management system for various purposes, including cutting down the restocking time for goods on sale or adjusting worker schedules. They are doing so with successful results, which are being replicated by different companies in the industry, and even in other sectors of the economy (Matusitz and Forrester 2009; Rajadell Carreras and Sánchez García 2010). However, no efforts are being made to apply lean manufacturing strategies that would allow the volumes requested from providers to be adjusted according to actual supermarket sales volumes. Why? We believe the reason is that this would not bring them any financial benefits. Or, better said, it would not lead to any reduction in their operating costs.

The oligopoly exerted by the major retailers in the agrofood chain allows them not only to impose their quality standards, as discussed earlier, but also to act as judges when it comes to deciding whether or not such standards are being met. This allows them to pass on to suppliers the consequences of their planning errors, or of their inability to efficiently manage such planning. All they have to do is apply their quality controls more or less rigorously as suits their needs. For instance, if the volume of a certain food item requested by the supermarket chain from its suppliers exceeds expected sales, it will apply more stringent control procedures, thereby allowing it to reject any surplus.

This strategy on the part of major retailers not only turns their planning errors into wasted food, it also encourages the production of food that, it is known beforehand, will end up being wasted. This is due, on the one hand, to the fact that supermarkets make no effort to improve their efficiency. It is an issue that generates zero cost to them, as they pass it on to the supplier. And on the other hand, it encourages a tendency to plan for a surplus; suppliers would rather end up with excess production than run the risk of a stock-out, which would result in the supermarket switching to another supplier or imposing the stiff penalty stipulated in its contract with the supplier. Even the risk of a poor harvest leads producers to plan their output in excess of contracted volumes. Hence, not only are perfectly healthy food items wasted because they do not match the appearance and size specifications set by the supermarket; there is also deliberate overproduction.

\section{c) Competing for access to the market}

As we have just discussed, farmers must grow products subject to the quality standards required of them, and in excess of contracted volumes, as a result of the major retailers' control over the market. But this is not the only reason behind overproduction. Another cause is the individual urge to maximize profit in a strongly competitive market. It is extremely unlikely that "the invisible hand" - that capacity for market selfregulation referred to by Adam Smith (2003) - should succeed in matching market demand with the decisions of millions of producers and reach an "equilibrium price" that really meets the needs and expectations of both consumers and suppliers. On the contrary, the fear of lagging behind, of not producing enough in a competitive market, drives producers constantly to increase their output. If farmer A achieves a greater increase in productivity, farmer B loses competitiveness and runs the risk of being marginalized from the market in the long run. This spiral is accelerated and incentivized by productivist public policies and by a growth-oriented ideology that colonizes mentalities.

This spiral has undesired effects, such as producer indebtedness. But the outcome that concerns us here is the risk of overproduction. Overproduction as a result of competitiveness and the application of industrial technology has taken place across the globe. Europe has been, and still is, an example of this. As a result of this process of scaling up production, the European Union started to face serious surplus farm production problems in the 1980s. For instance, production of sugar, wheat and milk stood at $140 \%, 124 \%$ and $118 \%$ respectively of European consumption needs (Serrano and Pinilla 2010). This led to excessive piling up of reserve stocks. It was no longer possible to place this surplus on the market, as it would have depressed farm prices below production costs, ruining farmers and destroying the production system in Europe. What to do then?

The European Union decided to replace the productivist agricultural matrix it had promoted since the 1960s with one that would integrate agriculture into broader economic and environmental objectives for the rural world. This new matrix was to be characterized by an adjustment of food production to internal demand 
(production quotas), progressive removal of public subsidies, greater environmental regulation of agriculture, and the incorporation of rural areas in the tertiary sector though tourism (Ilbery and Bowler 1998; Tangermann and Cramon-Taubadel 2013). As was forecast by David Harvey (1995), these post-productivist policies did not yield the expected results, or could not be fully implemented due to political pressures and the dependency on, and institutionalization of, the subsidy system. At best, such contradictions were resolved by introducing minimal environmental measures that did not change the development-driven logic of the model. This model has continued to generate major environmental impacts and contributes to the disappearance of small, familyrun farms that used to create jobs and drive the local economy, to the benefit of large agro-industrial corporations (Fritz 2011). Therefore, such policies give rise to a waste not only of material resources, but also of human ones: they lead to a "waste" of farmers - qualified specialists in the sustainable production of quality food.

Moreover, accession to the European Union by West European countries, with a strong rural and agricultural component, also led to rises in grain surpluses that had to be accepted in order to stop those economies from failing (Pouliquen 1998). Europe's solutions in order to get rid of such reserves ended up being, firstly, an artificial increase in exports. This caused the specter of dumping to become reality in many Globe South countries. In other words, parts the planet were flooded with cheap food (owing to the fact that a large part of its production cost was subsidized), thereby ruining local agricultural economies, which saw their markets flooded with foreign food products sold below production cost (Murphy, Lilliston and Lake 2005; Segrelles Serrano 2012; Sotomayor 1994). Formally, the European Union currently continues to generate surpluses, though in smaller quantities than in the 1980s. But what actually happens in practice is that exports have increased substantially, aided by this strategy: between 1988 and 2003, their volume doubled (Leguen de Lacroix 2004). By way of an example, Europe is the world's second-largest wheat exporter: between 2008 and 2011 it held a 17\% share of the global market. Wheat producers in Kenya, a country where production resources (land, water, and labor) are much cheaper, were unable to withstand competition from cheap European wheat, which came in the form of flour through Egypt and the Republic of Mauritius. This situation caused local market prices to plummet by $30 \%$ at the beginning of this century. The steps taken by the Kenyan government to counter this situation did not succeed in allaying the pressure. As a result: a) local flour factories stopped buying locally grown wheat; b) many farmers went bankrupt or were forced to switch to other crops (corn, dairy production); c) this led to increased dependency on food exports, thereby aggravating Kenya's food sovereignty problem; and d) the European wheat market was strengthened (Fritz 2011).

The second solution was the destruction of part of the surplus stockpiles, i.e. perfectly edible food. While this step became necessary in order to stop European and extra-European producers from going under as a result of yet more cheap exports, it was essentially illogical from a social and environmental standpoint: overproduction was the result of European policies themselves and the technification they had promoted. Up to one third of the funds of operating programs through which the European Union subsidizes fruit and vegetable producers can be used to "withdraw" part of their production from the market in order to avoid falls in prices. The actual meaning behind the euphemism "withdraw" is destruction, green harvesting (before ripening) or abandoning the produce in the fields (Official Journal of the European Union 2007). The contradiction is flagrant if we consider that, under its productivist policies, the European Union may end up subsidizing the destruction of food whose production it has previously subsidized.

\section{Waste in the food production process (II): waste of production resources}

As discussed earlier, Kling's definition of food waste extends to unnecessary use of agricultural resources ("... or the use of crops, livestock and livestock products in ways which return relatively little human food value"). What causes such misuse of resources?

Mainstream agricultural research has focused on productivity. Agroecology, however, has placed greater attention on the efficiency of agricultural systems or, in other words, on the appropriate (or inappropriate) utilization of available resources to produce food. This has provided it with tools to answer the question posed above. Agroecology has discovered that, while industrialized agriculture can increase food output volumes in 
the short term, this is usually achieved at the expense of implementing energy-inefficient models that can even put at risk the sustainability of available resources (Altieri 1995; Pimentel 2009).

The dominant agrofood model, based on a marketing process under the control of major retailers, drives producers toward technological modernization. As discussed earlier, product quality requirements (size, shape, color, etc.) force farmers to acquire certain technological packages. This is compounded by the volume and inventory demands imposed upon them by the retailers. Matching the agricultural cycle under the traditional production model with the level of demand from the mainstream market is hard to achieve. It is, however, possible to maintain a steady supply of products throughout the year with the appearance and other product specifications required by retail chains. But this calls for applying technology packages capable of overcoming the constraints imposed by the ecosystem and the agricultural cycle, thus replacing traditional harvests with standardized products. Industrial farming techniques are characterized by their ability to break away from the constraints of the agricultural cycle. By way of an example, the implementation of irrigation systems in dry farmlands allows two harvests to be obtained where only one was possible before. A further example is greenhouse technology, notably improved since the 1970s, which allows production regardless of existing weather and seasonal conditions.

The problem is that the adoption of these new technologies is not devoid of ill effects. On the one hand, it gives rise to radical changes in the social and economic structure of farming communities, which often ultimately marginalizes and impoverishes small and medium-sized farms and renders them more vulnerable. ${ }^{2}$ On the other hand, modern farming is characterized by strong environmental impacts: groundwater contamination caused by the use of synthesized chemicals, greenhouse gas emissions due to intensive use of fossil fuels, loss of biodiversity resulting from the narrower variety of seeds used, eutrophication of lake, river and marine systems due to contamination by nutrients originating from the use of synthesized fertilizers, spread of toxic species, disruption of the soil energy balance, etc. (Carson 1962; Cussó, Garrabou and Tello 2006; Tilman 1998).

The marketing model based on large retailers also imposes the need for specialized production. This arises in part from the need to acquire appropriate technology packages: each product or product family requires a specific technology package. It is, however, unthinkable for a small or medium-sized arm to acquire all the technology packages required for the diversified production it might wish to pursue. But the need for specialized production is above all due to the logistics requirements of the corporations supplied by a given farm: major retailers lack the capacity for, or any interest in, managing product diversification. One of the reasons is the required volume of supply. Large retail chains deal with high volumes, prompting them to seek specialized suppliers for each product, or brokers able to provide such a service. Their objective is to find the required quantity of each product on the doorstep of their warehouses, rather than having to bargain for small quantities with different producers and burden themselves with stock management issues. Therefore, the dominant agrofood marketing model tends to drive its suppliers toward specialization. Those who do not specialize cannot be suppliers to these corporations, and are therefore marginalized from the mainstream food market.

Specialization deepens the financial vulnerability of farms. On the one hand, as they specialize their production and lose market share in their traditional markets, they end up relying on just one (or a few) customers. On the other hand, reliance on a single product makes them highly dependent on the - always volatile - market price for that product. To this financial risk must be added the fact that specialization calls for using greater quantities of synthesized agricultural inputs (fertilizers, pesticides, fungicides, etc.). This is

\footnotetext{
${ }^{2}$ As this model favors monocrop farming in order to meet demand from a global market, economies of scale come into play. This promotes farmland concentration, and also water concentration, given the water-intensive nature of this production model. Public policies, steeped in the principles of the Green Revolution since World War II, supported largescale producers through various strategies, ranging from the reduction of taxes on agro-industrial inputs to direct subsidies to producers. Small farmers, marginalized from this aid granted to large-scale agricultural production, were barred from access to the market: they were unable to compete with subsidized industrial producers. Where small and medium-sized farmers incorporated the new technologies, they found themselves increasingly dependent on industrial inputs, the price of which tended to rise. Moreover, such technology was expensive; many peasants had to indebt themselves for life in order to acquire and maintain it. The bottom line was that the model benefitted large-scale producers, while peasant poverty rose (Bretón 2010; Lappé, Collins and Rosset 1998; Shiva 1991).
} 
due to the fact that the replenishment of soil nutrients is harder to achieve when one abandons traditional techniques such as crop rotation and association, characteristic of a diversified production model. A further reason is that plagues and diseases spread more easily when diversity is reduced, as pathogens tend to be highly specialized (Altieri and Nicholls 1994; Toledo and Barrera-Bassols 2008). The use of such industrial products can have adverse effects on soil nutrient balance and groundwater quality, thereby reducing a farm's productivity in the medium and long term (Garrabou Segura, Tello and Olarieta 2010; Marx 1986[1867]; Shiva 2005).

This industrial, productivist food production model is characterized by a considerable waste of agricultural resources. On the one hand, it generates nutrient waste. The crops generate biomass in the form of residue (pruning, stems, hay, leaves, etc.), while livestock production also generates residue with high nutrient content (manure). In diversified production models (peasant farming), these crop residues are incorporated back into the agricultural cycle by converting them into an input (fertilizer), either by plowing them back into the soil in preparation for the next harvest or by composting. This allows the nutrients in the soil to be replenished (Quenum et al. 2008; Norton and Reid 2013), as well as the preservation of the microfauna that plays a part in the production process (Julca-Otiniano et al. 2006). However, in the industrial production model, crop residues become waste. There is no use for all that biomass. In fact, it is seen as a nuisance, which even leads to its destruction by burning; this is also supposed to destroy weed seeds. Specialized production has no capacity for, or interest in, managing these resources, and therefore disposes of them. The replenishment of soil nutrients is achieved through the application of industrial, generally synthesized, fertilizers (Garrabou Segura, Tello and Olarieta 2010; McNeill and Winiwarter 2004; Tello Aragay 2004).

In some cases industrial production does make use of crop residue, but in an inefficient manner. For example, in the vast soya plantations in the Southern Cone the practice of "direct seeding" has become widespread. This involves spreading the seeds directly over the residue from the previous harvest without turning over the soil. Crop residue helps preserve soil moisture and reduce rain erosion. However, this use of residue without any preparation or tilling causes weeds and infestations to spread with greater virulence, requiring vast quantities of agrochemicals to fight them (Reboratti 2010).

This results in an energy-inefficient production model that converts large volumes of nutrients generated by the agricultural process into waste. The volume of agricultural waste that the industrial production model is unable to incorporate back into the agricultural cycle is so huge that its use as biofuel is being proposed in certain scientific circles (Lal 2005). Oscar Carpintero and José Manuel Naredo (2006) have calculated that industrial production methods give rise to a high energy deficit in Spanish agriculture. Specifically, they note that, in energy terms (i.e., kilocalorie calculations), the use of fertilizers (input) tripled between 1977 and 2000, while the rise in production (output) over that period only reached around $34 \%$. It should be recalled that the industrialization of agriculture is an imposition by the mainstream food marketing and distribution system.

Mention should likewise be made of the waste of fertile soil under the industrial agrofood model. For instance, monocrop production relies on large-scale use of machinery, which leaves out areas where it is unable to operate (uneven terrain, for example). These are areas that peasant farming, which operates on a small scale and is labor intensive, does make use of. But where soil waste becomes more evident is in regard to loss of fertility. This is how the nonprofit organization GRAIN explains the disastrous impacts of the agro-industrial model on agricultural soils:

According to a wide range of studies, agricultural soils in Europe and the United States have lost, on average, 1-2 percentage points of organic matter in the top $20-50 \mathrm{~cm}$. This figure may well be an underestimate, as most often the point of comparison is the organic matter level in the early twentieth century, when many soils had already been subjected to industrialised processes, and could have already lost large amounts of organic matter. Some soils in the agricultural mid-west in the USA contained 20 per cent carbon in the 1950s, and are now down to a mere 1-2 per cent. Studies in Chile, Argentina, Brazil, South Africa, and Spain report losses of up to 10 percentage points. Data provided by researchers of the University of Colorado indicate that the world average for organic matter loss in cultivated land is 7 percentage points. (GRAIN 2012: 115). 
In some instances, this loss of fertile soils has been swift and dramatic, as in the case of the Dust Bowl that devastated the North American Great Plains in the 1930s. Although the immediate cause was a severe drought, the root cause of the crisis lay in the use of inappropriate farming practices. The farmers that colonized that territory were driven toward the modernization and monocrop exploitation of their farms by the strong demand for wheat originated by World War I. Finally, over a number of years, great sandstorms blew away the fertile topsoil in the Great Plains and turned them into a desert (Phillips 1999; Worster 1979).

Fertile soil waste and food waste are closely related phenomena. The large amounts of food discarded in the marketing/consumption chain are a vector that impacts on the destruction of forests, pastures and marshlands. Efficient consumption of the food produced would slow down the advance of the agricultural frontier. A study conducted in Sweden revealed that just the food waste in public institutions serving food represented $1.5 \%$ of the country's farmland (Engström and Carlsson-Kanyama 2004).

\section{Conclusions}

Let us return to the two definitions with which we started the article. In the introduction we saw that the primary differentiating element between them is the unit of computation. Conventionally, units of mass and currency are used to assess food waste. But evaluating food waste in financial or volume terms rather than in terms of energy or nutrients, as suggested by Kling's definition and called for by political ecologists, excludes from analysis a substantial part of the problem. This is because lost resources cannot always be boiled down to dollars or tons.

In fact, what should otherwise be considered losses can even be represented as profits. Let us consider, by way of an example, a process to which we have referred earlier: the reuse of farm produce rejected in the field as a raw material for making compost. As demand has risen for certified organic food products, production of organic fertilizer has soared. Part of the produce that never enters, or is discarded from, the agrofood chain is used for this purpose. If we performed our calculation in terms of units of mass, the process might appear to be balanced: one ton of rejected food is converted into one ton of raw material used to make premium quality compost. We would seem to have full compensation. If our figures were based on currency units, we might even get the impression that the process is financially profitable: it generates an income that the farm will consider as net profit if the production cost and operating costs booked for the harvest have been applied to the produce that entered the food chain.

However, an analysis from a political ecology standpoint, based on energy or nutrient units, provides a very different perspective: we now find that the cost (in nutrients and energy) of producing a wasted food item greatly exceeds the benefit (in nutrients and energy) we can get back from it as an agricultural or energy input. The cost in terms of the energy and nutrients involved in the production of an apple greatly exceeds the energy and nutrients we get back from it as fertilizer. The energy and nutrient balance is negative. Composting reduces the shortfall in nutrients and energy resulting from food waste, but it is far from making up for it (Gascón 2018; Montagut and Gascón 2014). Consideration must also be given to the cost of the externalities, such as greenhouse gas emissions, among others, involved in producing, not to mention disposing of, food that is not consumed (Berners-Lee, Howard, Moss, Kaivanto and Scott 2011; Moult, Allan, Hewitt and Berners-Lee 2018).

Calculating food waste in terms of nutrients and energy flows allows us to go beyond a reductionist perspective of the food waste phenomenon. However, this approach is not devoid of difficulties. One such obstacle is the fact that the accounting tools developed over decades and centuries by economists (and the disciplines that analyze the agrofood industry in a conventional manner) reduce any economic activity to currency or mass units. A further obstacle is the fact that official statistics are generated on the basis of such conventional tools. How can a researcher approach the phenomenon of food waste from a broad, 'Klingian' perspective without suitable tools and primary data? It is a daunting challenge. Besides having to deal with skewed and inaccurate food statistics (Contreras Hernández 1996), our researcher would be faced with the task of developing such instruments and starting the process of compiling such data. Writing the present article required facing such limitations, using tangential data in some cases and extrapolating data in others. However, 
it is a line of research that needs to be pursued: food waste is too big and prominent an issue to be sidelined. Moreover, it features increasingly in the social, political and scientific agenda on food.

In order to break away from the prevailing reductionist outlook in the analysis of food waste, we need to acknowledge that conventional accounting systems do not reflect all the economic processes. In fact, they tend to fall into the trap of evaluating what can be measured, instead of measuring what needs to be evaluated. This is a more deeply ingrained trend when agricultural economics is involved. For instance, a substantial part of global food production takes place in peasant farms and goes to self-consumption (Weis 2007). However, for mainstream economics this reality does not exist, as it does not go through the market. The phenomenon of food waste exemplifies the Bourdieuan notion that the discipline of economics not only fails to describe reality, but makes an abstraction by dissociating a particular category of social practices. Such abstraction allows it to present alleged ideas as universal truths that legitimize the structure of society (Bourdieu 2000).

Lastly, we have mentioned that the FAO considers that the overproduction and waste of food is the result of logistical irrationality and inadequate technological development, which does not allow the actors forming part of the agrofood channel to establish suitable coordinated strategies. But we have also seen that the decision by a supermarket chain of contracting for 110 tons with the supplier when it expects it will only need 100 tons is a logical strategy suited to the operation of the industrial agrofood chain: the retailer thereby ensures the absence of stock-outs, and knows that it has enough power to burden the supplier with any surplus it may finally not require (contending, for instance, that the excess quantity does not meet the required quality standards). When that supplier schedules its production to obtain 120 tons instead of the 110 tons contracted with the supermarket chain, that is because it would rather produce in excess than fail to reach the agreed production target as, owing to the existing power balance, the consequences it would have to face for breach of contract would be extremely severe. The decisions of each actor in the agrofood chain are not irrational or due to poor logistics. The irrationality lies in the agrofood model. It is the model itself that causes them to adopt such strategies, which are entirely rational for their individual interests, in pursuit of which they operate an appropriate logistics and technological system.

Therefore, the root cause of this phenomenon lies not in logistics and technology factors, nor in the voraciousness of individuals, but in the dominant agro-industrial model and the unequal power relationship that characterizes it (O'Brien 2012). The problem and the solution are, above all, political. A Klingian analysis of food waste (i.e., in energy terms) may help to reveal this.

\section{References}

Altieri, M.A. and C. Nicholls. 1994. Biodiversity and pest management in agroecosystems. New York: Food Products Press.

Altieri, M.A. 1995. Agroecology: the science of sustainable agriculture. London: CABI.

Arancon, N.Q., C.A. Edwards, R. Atiyeh and J.D. Metzger. 2005. Effects of vermicomposts produced from cattle manure, food waste and paper waste on the growth and yield of peppers in the field. Pedobiologia 49(4): 297-306.

Awasthi, S.K., J.W.C. Wong, J. Li, Q. Wang, Z. Zhang, S. Kumar and M.K. Awasthi. 2017. Evaluation of microbial dynamics during post-consumption food waste composting. Bioresource Technology 251: 181-188.

Berners-Lee, M., D.C. Howard, J. Moss, K. Kaivanto and W.A. Scott. 2011. Greenhouse gas footprinting for small businesses - the use of input-output data. Science of the Total Environment 409(5): 883-891.

Binimelis, R., V. Escurriol and M.G. Rivera-Ferré. 2012. Soberanía alimentaria: transformación artesanal y equidad de género. Bilbao: Mundubat.

BIO Intelligence Service. 2012. Preparatory study on food waste across EU 27. Technical Report - 2010 - 054. Brussels: European Commission.

Bourdieu, P. 2000. Les structures sociales de l'économie. Paris: Éditions du Seuil.

Bretón, V. 2010. La tenaz persistencia de la subnutrición o los límites del desarrollo. In Bretón, V. (ed.) Saturno devora a sus hijos: miradas críticas sobre el desarrollo y sus promesas. Barcelona: Icaria. Pp. 197-243. 
Cadieux, K.V. and R. Slocum. 2015. What does it mean to do food justice? Journal of Political Ecology 22(1): $1-26$.

Carpintero, O. 2006 La bioeconomía de Georgescu-Roegen. Madrid: Montesinos.

Carpintero, O. and J.M. Naredo. 2006. Sobre la evolución de los balances energéticos de la agricultura española, 1950-2000. Historia Agraria 40: 531-554.

Carson, R.L. 1962. Silent spring. Boston: Houghton Mifflin.

COAG. 2014. Anuario Agrario 2014: el campo, puerta abierta al futuro. Madrid: COAG.

Contreras Hernández, J. 1996. Estadísticas y pautas de consumo: ¿Sabemos realmente lo que comemos? In Medina, F.X. (ed.). La alimentación meditarránea: historia, cultura, nutrición. Barcelona: Icaria. Pp. $137-162$.

Cussó, X., R. Garrabou, and E. Tello. 2006. Social metabolism in an agrarian region of Catalonia (Spain) in 1860-1870: flows, energy balance and land use. Ecological Economics 58(1): 49-65.

Devin, B. and C. Richards. 2018. Food waste, power, and corporate social responsibility in the Australian food supply chain. Journal of Business Ethics 50(1): 199-210.

Dolan, C. and J. Humphrey. 2000. Governance and trade in fresh vegetables: the impact of UK supermarkets on the African horticulture industry. The Journal of Development Studies 37(2): 147-176.

Engström, R. and A. Carlsson-Kanyama. 2004. Food losses in food service institutions: examples from Sweden. Food Policy 29(3): 203-213.

Fjelda, C.R. and R. Sommera. 1982. Regional-seasonal patterns in produce consumption at farmers' markets and supermarkets. Ecology of Food and Nutrition 12(2): 109-115.

Freidberg, S. 2003. Cleaning up down South: supermarkets, ethical trade and African horticulture. Social and Cultural Geography 4(1): 27-43.

Freidberg, S. 2004. The ethical complex of corporate food power. Environment and Planning D: Society and Space 22(4): 513-531.

Freidberg, S. 2007. Supermarkets and imperial knowledge. Cultural Geographies 14(3): 321-342.

Freidberg, S. 2017. Big food and little data: the slow harvest of corporate food supply chain sustainability initiatives. Annals of the American Association of Geographers 107(6): 1389-1406.

Fritz, T. 2011. Globalising hunger: food security and the EU's Common Agricultural Policy. Berlin: Transnational Institute, Ecologistas en Acción, FCCL, Védegylet.

Garrabou Segura, R., E. Tello and J.R. Olarieta. 2010. La reposición histórica de la fertilidad y el mantenimiento de las capacidades del suelo, un elemento fundamental de las buenas prácticas agrícolas y su sostenibilidad. In Garrabou Segura, R. and M. González de Molina (eds.) La reposición de la fertilidad en los sistemas agrarios tradicionales. Barcelona: Icaria. Pp. 23-38.

Gascón, J. 2018. Comida no comida. Un análisis del desperdicio de alimentos desde la agroecología. In Observatorio de la Alimentación (ed.). Polisemias de la alimentación: salud, desperdicio, hambre y patrimonio. Barcelona: Universitat de Barcelona.

Gascón, J., C. Larrea, J. Ribas and C. Solà. 2017. Estudi preliminar sobre el malbaratament en la producció de fruita d'os a la província de Lleida. Barcelona, Observatori de l'Alimentació - Universitat de Barcelona (unpublished).

Ghezán, G., M. Mateos and L. Viteri. 2002. Impact of supermarkets and fast-food chains on horticulture supply chains in Argentina. Development Policy Review 20(4): 389-408.

Gille, Z. 2012. From risk to waste: global food waste regimes. The Sociological Review 60(2): 27-46.

Gorenstein, S. 1998. Sector agroalimentario: las relaciones industria/gran distribución. Desarrollo Económico 38(149): 457-476.

GRAIN. 2012. The great food robbery: how corporations control food, grab land and destroy the climate. Cape Town: Pambazuka Press.

Gustavsson, J., C. Cederberg and U. Sonesson. 2011. Global food losses and food waste. Roma: FAO. 
Harvey, D.R. 1995. European Union cereals policy: an evolutionary interpretation. Australian Journal of Agricultural and Resource Economics 39(3): 193-217.

Hattersley, L., I. Bronwyn and D. Burch. 2013. Supermarket power, own-labels, and manufacturer counterstrategies: international relations of cooperation and competition in the fruit canning industry. Agriculture and Human Values 30(2): 225-233.

Holt-Giménez, E. 2011. Food movements unite! Strategies to transform our food systems. Oakland: Food First Books.

Ilbery, B. and I. Bowler. 1998. From agricultural productivism to post-productivism. In Ilbery, B. (ed.) The geography of rural change. Essex: Pearson. Pp. 57-84.

Julca-Otiniano, S., L. Meneses-Florián' R. Blas-Sevillano and S. Bello-Amez. La materia orgánica: importancia y experiencia de su uso en la agricultura. Idesia 24(1): 49-61.

Kiran, E.U., A.P. Trzcinskia, W.J. Nga and D. Yu Liu. 2014. Bioconversion of food waste to energy: a review. Fuel 134: 389-399.

Kling, W. 1943. Food waste in distribution and use. American Journal of Agricultural Economics 25(4): 848859.

Kumar, M., Y.-L. Ou and J.-G. Lin. 2010. Co-composting of green waste and food waste at low C/N ratio. Waste Management 30(4): 602-609.

Lal, R. 2005. World crop residues production and implications of its use as a biofuel. Environment International 31(4): 575-584.

Lappé, F.M., J. Collins and P. Rosset. 1998. World hunger: twelve myths. New York: Grove Press.

Lee, J.-J., R.D. Park, Y-W. Kim, J.-H. Shim, D.H. Chae, Y-S. Rim, B-K. Sohn, T-H. Kim and K.Y. Kim. 2004. Effect of food waste compost on microbial population, soil enzyme activity and lettuce growth. Bioresource Technology 93(1): 21-8.

Leguen de Lacroix, E. 2004. The Common Agricultural Policy explained. Germany: European Commission Directorate General for Agriculture.

Macías Huerta, M.C. and C. Valdivia Preciado. 2003. Cambio de hábitos de consumo femenino en la zona metropolitana de Guadalajajara, Jalisco, México. Sincronía 26.

Martínez Alier, J. 1994. De la economía ecológica al ecologismo popular. Barcelona: Icaria.

Martinez Alier, J. 2004. Political ecology, distributional conflicts, and economic incommensurability. In Redclift, M. (ed.) Sustainability: critical concepts in the social sciences. London: Routledge. Pp. 395415.

Marx, K. 1986 [1867]. Capital: a critique of political economy: the process of production of capital. Vol. 1. Moscow: Progress.

Matusitz, J. and M. Forrester. 2009. Successful glocalization practices: the case of Seiyu in Japan. Journal of Transnational Management 14(2): 155-176.

McGrath, M. 2013. UK supermarkets reject 'wasted food' report claims. BBC News (January 10). [accessed December 19 2017] http://www.bbc.com/news/uk-20968076

McNeill, J.R. and V. Winiwarter. 2004. Breaking the sod: humankind, history, and soil. Science 304(5677): 1627-1629.

Moisio, R., E.J. Arnould and L.L. Price. 2004. Between mothers and markets: constructing family identity through homemade food. Journal of Consumer Culture 4(3): 361-384.

Mol, A.P. and H. Bulkeley. 2002. Food risks and the environment: changing perspectives in a changing social order. Journal of Environmental Policy and Planning 4(3): 185-195.

Montagut, X. and J. Gascón. 2014. Alimentos desperdiciados: un análisis del derroche alimentario desde la soberanía alimentaria. Barcelona: Icaria.

Montagut, X. and E. Vivas (eds.). 2007. Supermercados, no gracias: grandes cadenas de distribución: impactos y alternativas. Barcelona: Icaria. 
Moult, J.A., S.R. Allan, C.N. Hewitt and M. Berners-Lee. 2018. Greenhouse gas emissions of food waste disposal options for UK retailers. Food Policy 77: 50-58.

Murphy, S., B. Lilliston and M. Lake. 2005. WTO agreement on agriculture: a decade of dumping. Minnesota: The Institute for Agriculture and Trade Policy.

Norton, D. and N. Reid. 2013. Nature and farming: sustaining native biodiversity in agricultural landscapes. Colliingwood: CSIRO.

O'Brien, M. 2012. A 'lasting transformation' of capitalist surplus: from food stocks to feedstocks. The Sociological Review 60(2): 192-211.

Official Journal of the European Union. 2007. Council Regulation (EC) No 1182/2007 of 26 September 2007 laying down specific rules as regards the fruit and vegetable sector, amending Directives 2001/112/EC and 2001/113/EC and Regulations (EEC) No 827/68, (EC) No 2200/96, (EC) No 2201/96, (EC) No 2826/2000, (EC) No 1782/2003 and (EC) No 318/2006 and repealing Regulation (EC) No 2202/96. [accessed December 20 2017] http://eur-lex.europa.eu/eli/reg/2007/1182/oj

Parfitt, J., M. Barthel and S. Macnaughton. 2010. Food waste within food supply chains: quantification and potential for change to 2050. Philosophical Transactions of the Royal Society B 365: 3065-3081.

Phillips, S.T. 1999. Lessons from the Dust Bowl: dryland agriculture and soil erosion in the United States and South Africa, 1900-1950. Environmental History 4(2): 245-266.

Pimentel, D. 2009. Reducing energy inputs in the agricultural production system. Monthly Review 61(3): 92101.

Pisani, M.J. and D.W. Yoskowitz. 2012. A study of small neighborhood Tienditas in Central America. Latin American Research Review 47(4): 116-138.

Pouliquen, A. 1998. Agricultural enlargement of the EU under Agenda 2000: surplus of farm labour versus surplus of farm products. Economics of Transition 6(2): 505-522.

Prieto, M. J.M. Mouwen, S. López Puente and A. Cerdeño Sánchez. 2008. Concepto de calidad en la industria agroalimentaria. Interciencia: Revista de Ciencia y Tecnología de América 33(4): 258-264.

Quenum, L., M.R. Albiach, M. Ribó, M. Estela, R. Canet, C. Baixauli, J.M. Aguilar and F. Pomares. 2008. Modificación de las propiedades del suelo provocada por diferentes modalidades de gestión de los restos de cultivos hortícolas bajo producción ecológica e integrada. VIII Congreso SEAE. Bullas (Murcia).

Rajadell Carreras, M. and J.L. Sánchez García. 2010. Lean manufacturing: la evidencia de una necesidad. Madrid: Ediciones Díaz de Santos.

Reardon, T. and R. Hopkins. 2006. The supermarket revolution in developing countries: policies to address emerging tensions among supermarkets, suppliers and traditional retailers. The European Journal of Development Research 18(4): 522-545.

Reboratti, C. 2010. Un mar de soja: la nueva agricultura en Argentina y sus consecuencias. Revista de Geografia Norte Grande 45: 63-76.

Ribeiro, S. 2007. Supermercados, ¿nueva pesadilla campesina? In Montagut, X. and E. Vivas (eds.). Supermercados, no gracias: grandes cadenas de distribución: impactos y alternativas. Barcelona: Icaria. Pp. 61-64.

Richards, C., H. Bjørkhaug, G. Lawrence and E. Hickman. 2013. Retailer-driven agricultural restructuring: Australia, the UK and Norway in comparison. Agriculture and Human Values 30(2): 235-245.

Rimal, A., S.M. Fletcher, K.H. McWatters, S.K. Misra and S. Deodhar. 2008. Perception of food safety and changes in food consumption habits: a consumer analysis. International Journal of Consumer Studies 25(1): 43-52.

Ronald, F., M. William and B. Harper. 1967. Correlates of grocery product consumption rates. Journal of Marketing Research 4(2): 184-190.

Rosales, E., S. Rodríguez Couto and S. Sanromán. 2002. New uses of food waste: application to laccase production by Trametes hirsuta. Biotechnology Letters 24(9): 701-704. 
Schwentesius, R. and M.A. Gómez. 2002. Supermarkets in Mexico: impacts on horticulture systems. Development Policy Review 20(4): 487-502.

Segrelles Serrano, J.A. 2012. La política agrícola común de la Unión Europea y la soberanía alimentaria de América Latina: una interrelación dialéctica. Scripta Nova XVI(415)

Serrano, R. and V. Pinilla. 2010. Agricultural and food trade in European Union countries, 1963-2000: a gravity equation approach. Documento de Trabajo AEHE 1007. Asociación Española de Historia Económica.

Shiva, V. 2005. Globalization's new wars: seed, water and life forms. New Delhi: Women Unlimited.

Shiva, V. 1991. The violence of Green Revolution: third world agriculture, ecology and politics. London: Zed.

Siniscalchi, V. 2013. Environment, regulation and the moral economy of food in the Slow Food movement. Journal of Political Ecology 20: 295-305.

Smith, A. 2003 [1776]. The wealth of nations. New York: Bantam.

Soil Association (n.d.) Feeding the future: how organic farming can help feed the world. Bristol: Soil Association.

Sotomayor, O. 1994. Políticas de modernización y reconversión de la pequeña agricultura tradicional chilena. Santiago de Chile: ODEPA and IICA.

Stedile, J.P. 2010. Las tendencias del capital sobre la agricultura. América Latina en Movimiento 459: 1-6.

Stuart, T. 2009. Waste: uncovering the global food scandal. New York: WW Norton \& Company.

Swinnen, J.F.M. 2010. The political economy of agricultural and food policies: recent contributions, new insights, and areas for further research. Applied Economic Perspectives and Policy 32(1): 33-58.

Tangermann, S. and S. von Cramon-Taubadel. 2013. Agricultural policy in the European Union: an overview. Diskussionspapiere, n. 1302. Department für Agrarökonomie und Rurale Entwicklung.

Tello Aragay, E. 2004. Desenvolupament sostenible a l'agricultura: l'evolució, la història i els criteris operatius. In Argemí d'Abadal, L. and M. Rodríguez Rodríguez-Zúñiga (eds.) L'agricultura moderna: de l'alimentació al medi ambient. Barcelona: Universitat de Barcelona. Pp. 83-152.

Tilman, D. 1998. The greening of the green revolution. Nature 396: 211-212.

Toledo, V.M. and N. Barrera-Bassols. 2008. La memoria biocultural: la importancia ecológica de las sabidurías tradicionales. Barcelona: Icaria.

Warner, D., J. Tzilivakis and K. Lewis. 2005. Sustainability of UK strawberry crop: final report to DEFRA for Research Project HH3606. Hertfordshire: University of Hertfordshire - Department for Environment, Food and Rural Affairs.

Waste Management World. 2013. Biffa helps birds eye close in on 'zero waste'" WMW. [accesed December 19 2017] http://www.waste-management-world.com/articles/2012/03/biffa-helps-birds-eye-close-in-onzero-waste-.html

Weis, T. 2007. The global food economy: the battle for the future of farming. London: Zed Books.

Willow, A.J. 2014. The new politics of environmental degradation: un/expected landscapes of disempowerment and vulnerability. Journal of Political Ecology 21(1): 237-257.

Wood, W. 2007. Purchase and consumption habits: not necessarily what you intend. Journal of Consumer Psychology 17(4): 261-276.

Worster, D. 1979. Dust Bowl: the Southern Plains in the 1930s. New York: Oxford University Press.

Yasin, N.H.M., T. Mumtaz and M.A. Hassan. 2013. Food waste and food processing waste for biohydrogen production: a review. Journal of Environmental Management 130: 375-385. 